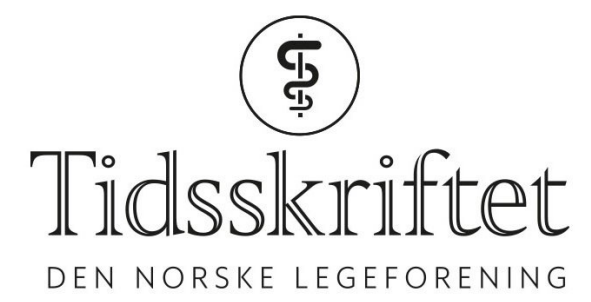

\title{
Hvem skal få dyre kreftmedisiner?
}

DEBATT

\section{HAAKON LINDEKLEIV}

E-post: haakon.lindekleiv@unn.no

Haakon Lindekleiv er lege og fagsjef ved Universitetssykehuset Nord-Norge og førsteamanuensis ved Universitetet i Tromsø.

Forfatteren har fylt ut ICMJE-skjemaet og oppgir ingen interessekonflikter.

\section{MARIUS STORVIK}

Marius Storvik er jurist og førsteamanuensis ved Universitetet i Troms $\emptyset$. Forfatteren har fylt ut ICMJE-skjemaet og oppgir ingen interessekonflikter.

Helsetilsynet avgjorde nylig i en enkeltsak at det offentlige må fortsette privat betalt immunterapi. Vedtaket kan få uønskede konsekvenser for prinsippet om likeverd og hvordan nye metoder innføres.

Statens helsetilsyn behandlet nylig en klage der et helseforetak hadde sagt nei til å dekke utgiftene til immunterapi for en kreftsykdom (1). Det forelå ikke markedsføringstillatelse for legemiddelet for den aktuelle kreftsykdommen, og behandlingen var ikke innført ved norske sykehus. Pasienten hadde startet behandlingen utenfor godkjent indikasjon (off label) ved et privat sykehus. Vedkommende hadde effekt av legemiddelet og ønsket at det offentlige skulle overta kostnadene for videre behandling. Saken var først innklaget til Fylkesmannen i Oslo og Akershus, som ikke ga pasienten medhold. Helsetilsynet vurderte at helseforetaket ved sitt vedtak hadde brutt pasientrettighetsloven $\S 2-1 \mathrm{~b}$ om rett til nødvendig helsehjelp fra spesialisthelsetjenesten. Tilsynet vurderte det som uforsvarlig at helseforetaket ikke fortsatte behandlingen som pasienten selv hadde besørget gjennom en privat tilbyder og hatt effekt av.

Vår kjennskap til saken er gjennom en anonymisert kopi av vedtaket. Vi ønsker verken å stille spørsmål ved eller støtte de juridiske vurderingene i Helsetilsynets vedtak, men $\emptyset n s k e r$ å belyse mulige uønskede konsekvenser av vedtaket. Dette gjelder både helseforetakenes forvaltning av unntaksordningen og hvordan klinikere skal informere pasienter. Vedtaket kan også øke risikoen for en ytterligere privatisering av helsevesenet og at det blir mindre til ressurssvake pasienter.

\section{Spørsmål om prioriteringer}

De siste årene er det utviklet mange dyre kreftlegemidler. Dette gir store økonomiske utfordringer for sykehusene. Ettersom sykehusene ikke tilføres øremerkede midler fra staten til dette, må helseforetakene finansiere $\emptyset$ kte utgifter gjennom sine ordinære rammer. Det kan innebære færre investeringer og kutt i tilbudet til andre, lavere prioriterte pasientgrupper. 
Samfunnet har begrensede ressurser, og ingen pasientgrupper har ubegrenset tilgang til alle nye legemidler. For å hindre at beslutninger om finansiering av legemidler er tilfeldige, er det etablert tre nasjonale kriterier for prioritering: ressursbruk, nytte og alvorlighet (2). Formålet med prioriteringskriteriene er å sikre likeverd og ivareta alle på like premisser. I dag er det Beslutningsforum for nye metoder som vurderer om nye legemidler skal innføres i det offentlige (3). Forut for godkjenningen gjøres det en metodevurdering for å sikre at det eksisterer god dokumentasjon for effekt.

Som hovedregel skal man ikke bruke legemidler som ikke er besluttet innført av Beslutningsforum. I dag kan ledelsen ved et helseforetak gjøre unntak for enkeltpasienter og dekke utgifter til legemidler som gis utenfor godkjent indikasjon, eller til legemidler som er under metodevurdering. Utgiftene til legemiddelet dekkes da i sin helhet av helseforetaket.

Lovgivningen gir pasientene individuelle rettigheter, mens systemet vurderer pasientene som grupper

\section{Målet om en likeverdig tjeneste}

Den umiddelbare konsekvensen av Helsetilsynets vedtak er at helseforetakene i vurderingen av søknader om unntak må legge til grunn hvorvidt pasienten har kjøpt behandling privat og hatt effekt av det. Gjennom dette kan man indirekte legge til rette for at pasienter i økende grad vil kjøpe eksperimentell behandling ved private sykehus.

Dette utfordrer målet om en likeverdig helsetjeneste. Det er bred politisk enighet om at ressurssterke pasienter ikke skal prioriteres på bekostning av andre. Kreftpasienter som har råd til å betale privat for legemidler som ikke er godkjent i det offentlige, vil nå (dersom de har effekt av behandlingen) kunne motta videre behandling gratis ved offentlige sykehus. Tilsvarende kan man tenke seg at vi risikerer en praksis der legemiddelfirmaer tilbyr pasienter rabattert prøvebehandling med et legemiddel som ikke er godkjent i det offentlige for så å hente inn igjen fortjenesten gjennom økte priser på legemidlene etter prøveperioden.

Videre kan det være vanskelig å vurdere om behandlingseffekten hos en enkeltpasient kan tilskrives et legemiddel som ikke har markedsføringstillatelse for den aktuelle indikasjonen. I randomiserte studier av kreftlegemidler foreligger det ofte progresjonsfri overlevelse hos en betydelig andel av pasienter som har fått placebo. Dette er et prinsipielt problem ved individuell vurdering av legemidler der effekten og sikkerheten ikke er tilstrekkelig dokumentert for den aktuelle indikasjonen.

\section{Møte mellom lovgivningen og systemet}

Hva skal norske leger gjøre? Skal pasienten informeres om muligheten til å selv betale for et forsøk med legemiddelet ved et privat sykehus for så å få kunne søke helseforetaket om å dekke utgiftene dersom behandlingen har effekt? Dersom legen tar utgangspunkt i pasienten foran seg, er svaret kanskje ja. Dersom legen tar utgangspunkt i ønsket om mest mulig helse for flest mulig, er kanskje svaret nei. For legemidler med markedsføringstillatelse og god dokumentasjon av effekt står man som lege kanskje etisk og juridisk tryggest når man tilbyr pasientene informasjon (4).

Helsetilsynets vedtak synliggjør en svakhet i møtet mellom lovgivningen og systemet når det skal tas stilling til hvilke metoder som skal tilbys i spesialisthelsetjenesten.

Lovgivningen gir pasientene individuelle rettigheter, mens systemet vurderer pasientene som grupper.

Det er nylig foreslått flere endringer i spesialisthelsetjenesteloven (5). I lovforslaget presiseres det at pasienter ikke skal ha anledning til å betale for en høyere standard på helsehjelpen enn det som tilbys i den offentlige spesialisthelsetjenesten. Den offentlige spesialisthelsetjenesten skal heller ikke bistå med administrering eller oppfølging av 
legemidler som er kjøpt av pasienten og som er besluttet ikke tatt i bruk i den offentlige spesialisthelsetjenesten. Slik vi leser de foreslåtte lovendringene, ville ikke Helsetilsynets vedtak fått et annet utfall. Lovforslaget er til behandling i Stortinget. Helse- og omsorgskomiteen har da en mulighet til å ta stilling til problemstillingene som har oppstått.

\section{LITTERATUR:}

1. Helsetilsynet. Tilsynssak 2018/1992.

https://www.helsetilsynet.no/presse/nyhetsarkiv/2019/statens-helsetilsyn-har-som-overordnet-myndig het-omgjort-fylkesmannens-avgjorelse-om-avslag-pa-behandling-med-immunterapi/ Lest 14.8.2019.

2. Stortingsmelding 34 (2015-2016). Verdier i pasientens helsetjeneste - Melding om prioritering. https://www.regjeringen.no/no/dokumenter/meld.-st.-34-20152016/id2502758/ Lest 14.8.2019.

3. Beslutningsforum. Om systemet. https://nyemetoder.no/om-systemet Lest 14.8.2019.

4. Solberg B, Dahl T. Informere eller ikke informere? Tidsskr Nor Legeforen 2018; 138. doi: 10.4045/tidsskr.18.0265. [CrossRef]

5. Prop. 55 L (2018-2019). https://www.regjeringen.no/no/dokumenter/prop.-55-l-20182019/id2633049/ Lest 14.8.2019.

Publisert: 7. oktober 2019. Tidsskr Nor Legeforen. DOI: 10.4045/tidsskr.19.0517

(C) Tidsskrift for Den norske legeforening 2020. Lastet ned fra tidsskriftet.no 